\title{
PENGARUH PROFITABILITAS, LIKUIDITAS, SOLVABILITAS, DAN UKURAN PERUSAHAAN TERHADAP AUDIT REPORT LAG PADA PERUSAHAAN YANG TERDAFTAR DI BURSA EFEK INDONESIA
}

\author{
(Studi Kasus Pada Sektor Manufaktur)
}

\author{
Justita Dura \\ Dosen STIE ASIA Malang
}

\section{ABSTRAKSI}

Penelitian ini bertujuan untuk mengetahui pengaruh profitabilitas, likuiditas, solvabilitas dan ukuran perusahaan terhadap audit report lag pada perusahaan manufaktur yang terdaftar di Bursa Efek Indonesia periode 2013-2015. Jumlah sampel yang digunakan sebanyak 105 perusahaan berdasarkan metode nonprobability sampling dengan teknik purposive sampling. Teknik analisis yang digunakan adalah analisis regresi linear berganda. Hasil penelitian menunjukkan bahwa (1) profitabilitas berpengaruh terhadap audit report lag mengindikasikan bahwa perusahaan yang mendapatkan profit yang besar cenderung melakukan proses audit lebih singkat dibanding perusahaan yang mengalami profit yang kecil. (2) likuiditas berpengaruh terhadap audit report lag, (3) solvabilitas berpengaruh terhadap audit report lag mengindikasikan bahwa tingginya jumlah hutang yang dimiliki perusahaan akan menyebabkan proses audit yang relatif lebih panjang, dan (4) ukuran perusahaan berpengaruh terhadap audit report lag yang mengindikasikan bahwa besar atau kecilnya jumlah aset yang dimiliki oleh perusahaan mempunyai mempengaruhi panjang atau pendeknya proses penyusunan laporan keuangan pada perusahaan tersebut.

Kata kunci: Profitabilitas, Likuiditas, Solvabilitas, Ukuran Perusahaan, Audit Report Lag

\section{ABSTRACT}

This study aims to determine the effect of profitability, solvency and size of the company to the audit report lag in manufacturing companies listed in Indonesia Stock Exchange 2010-2013. The samples used as many as 105 companies with purposive sampling technique. The analysis technique used is multiple linear regression analysis. The results showed that (1) the profitability affect audit report lag indicates that companies that get a big profit tends to make the process shorter than audit firms experienced a small profit. (2) the liquidity affect audit report lag, (3) the solvency effect indicates that the high amount of debt of the company will lead the audit process is relatively long, and (4) the size of the company does affect indicating that a large or small amount of assets owned by the company does affect the length or in short the process of preparing the financial statements of the company.

Keywords: Profitability, Liquidity, Solvency, Company Size, Audit Report Lag

\section{PENDAHULUAN}

Laporan keuangan adalah hasil akhir dari siklus akuntansi setelah adanya penjurnalan, posting ke buku besar, jurnal penyesuaian, dan neraca lajur. Menurut Accounting Terminology Buletin No 1, akuntansi merupakan metode pencatatan, pengklasifikasian, dan pengikhtisaran transaksi atas kejadian yang bersifat keuangan dalam satuan uang, serta menginterpretasikan hasilhasilnya (Hendriksen dan Van Breda, 2000). Selain itu definisi akuntansi menurut Jusup (1994) akuntansi merupakan serangkaian kegiatan mencatat, menggolongkan, meringkas, melaporkan dan menganalisis data keuangan suatu organisasi sehingga terbentuk sebuah laporan keuangan.

Transaksi merupakan suatu aktivitas yang mempunyai nilai ekonomis bagi perusahaan. Aktivitas tersebut tercatat dalam jurnal dan secara periodik di posting dalam buku besar. Dimana pada akhir periode, saldo-saldo dari semua rekening yang terdapat dalam buku besar dihitung dan dimasukan ke dalam neraca lajur. Neraca lajur merupakan aktivitas yang digunakan untuk menyusun sebuah laporan keuangan.

Agar laporan keuangan dapat berguna bagi para pemakai laporan keuangan harus mengandung 
karakteristik yaitu dapat dipahami, relevan, andal, dan dapat diperbandingkan (IAI, 2007 dalam Sari, 2011). Laporan keuangan yang dihasilkan dapat membantu semua pengguna untuk mengetahui kondisi keuangan suatu entitas serta membantu dalam membuat keputusan dalam bidang ekonomi (Haron et al., 2006 dalam Sari, 2011). Salah satu yang menjadi kendala dalam penyajian laporan keuangan yaitu ketepatan waktu dimana seharusnya laporan keuangan itu di audit oleh akuntan public agar dapat dipublikasikan oleh masyarakat umum.

Batas waktu pada akhir periode akuntansi dengan tanggal ditandatanganinya laporan audit oleh seorang auditor dapat mempengaruhi ketepatan waktu informasi laporan keuangan yang dipublikasikan, dengan demikian ketepatan waktu pelaporan merupakan catatan penting dalam laporan keuangan yang memadai. Pengguna informasi tidak hanya memiliki informasi keuangan yang relevan dan pembuatan sebuah keputusan, tetapi informasi laporan keuangan harus bersifat baru. Laporan keuangan seharusnya disajikan pada interval waktu yang tepat guna dapat menjelaskan perubahan yang terjadi dalam sebuah perusahaan yang memungkikan adanya perubahan informasi dalam membuat prediksi dan pengambilan keputusan. Oleh karena itu penulis melaksanakan penelitian dengan judul "Pengaruh Profitabilitas, Likuiditas, Solvabilitas, Dan Ukuran Perusahaan Terhadap Audit Report lag Pada Perusahaan Yang Terdaftar Di Bursa Efek Indonesia (Studi Kasus Pada Sektor Manufaktur)"

\section{Rumusan Masalah}

Ketepatan waktu dalam penyajian laporan keuangan serta laporan atas audit merupakan sumber pokok dalam peningkatan harga pasar saham perusahaan. Perusahaan manufaktur yang memiliki asset yang lebih banyak dalam bentuk fisik daripada bentuk nilai moneter misalnya persediaan, aktiva tetap, dan aktiva tidak berwujud, sehingga menyebabkan seorang auditor membutuhkan waktu yang lebih lama untuk melakukan proses audit pada perusahaan manufaktur yang akan diaudit. Oleh karena itu banyak perusahaan melakukan audit report lag yang tidak sesuai dengan ketentuan yang ditetapkan oleh BAPEPAM. Berdasarkan perumusan permasalahan diatas permasalahan yang muncul adalah :
1. Apakah profitabilitas berpengaruh terhadap audit report lag?

2. Apakah likuiditas berpengaruh terhadap audit report lag?

3. Apakah solvabilitas berpengaruh terhadap audit report lag?

4. Ukuran perusahaan berpengaruh negatif terhadap audit report lag?

\section{Tujuan Penelitian}

Tujuan yang dicapai dalam penelitian ini adalah untuk mengetahui profitabilitas, likuiditas, solvabilitas, dan ukuran perusahaan mempunyai pengaruh terhadap audit report lag pada perusahaan manufaktur yang terdaftar di Bursa Efek Indonesia.

\section{Tinjauan Pustaka}

Menurut Ang (1997) rasio profitabilitas adalah salah satu keberhasilan suatu perusahaan dalam menghasilkan keuntungan. Tingkat profitabilitas dalam perusahaan mencerminkan keefektifitasan yang harus dicapai oleh suatu operasional perusahaan. Keuntungan suatu perusahaan merupakan salah satu cara untuk menilai keberhasilan efektifitas sebuah perusahaan, yang berkaitan dengan berbagai kebijakan dan keputusan perusahaan yang telah dilaksanakan oleh perusahaan dalam suatu periode akuntansi. Indikator rasio profitabilitas yang digunakan dalam menggunakan sistem Return on Assets (ROA).

Dalam penelitian Listiana dan Susilo (2012) menyatakan bahwa profitabilitas berpengaruh negatif terhadap audit report lag. Serta menurut Hilmi dan Ali (2007), Merdekawati (2010), Ansah (2000) dan Rachmawati (2009) menyatakan bahwa profitabilitas berpengaruh positif terhadap report lag perusahaan. Begitu pula dengan Parwati dan Suhardjo (2009) menyatakan bahwa profitabilitas berpengaruh terhadap audit report lag, tetapi berbeda dengan hasil yang ditunjukkan oleh Tiono dan Jogi (2012) yang menyatakan bahwa profitabilitas tidak berpengaruh terhadap audit report lag.

\section{Likuiditas}

Dalam penelitian Riyanto (1995) menyatakan bahwa likuiditas itu berhubungan dengan mengenai kemampuan sebuah perusahaan untuk memenuhi kewajiban finansialnya yang segera harus dipenuhi. Sedangkan menurut Munawir (2001) likuiditas itu menunjukkan kemampuan suatu perusahaan untuk memenuhi kewajiban atau hutang-hutangnya pada saat 
ditagih. Artinya bahwa likuiditas merupakan suatu kemampuan untuk memenuhi kebutuhan jangka pendeknya.

Current Ratio yang digunakan sebagai alat untuk mengukur likuiditas suatu perussahaan, serta sebagai petunjuk dalam mengetahui dan menduga sampai di manakah kemampuan sebuah perusahaan untuk memenuhi kewajiban keuangannya (Tunggal, 1995).

\section{Solvabilitas}

Solvabilitas merupakan kemampuan perusahaan dalam memenuhi segala kewajiban keuangannya pada saat perusahaan dilikuidasi. Menurut Carslaw dan Kaplan (1991) dalam Rachmawati (2008) menyatakan bahwa prosentase dari hutang terhadap total aset mengindikasikan adanya kondisi keuangan dari sebuah perusahaan. Prosentase yang tinggi dari hutang terhadap total asset akan membawa pengaruh solvabilitas yang terkait dengan masalah kelangsungan hidup sebuah perusahaan, sehingga perlu adanya kecermatan yang lebih dalam melakukan pengauditan (Rachmawati 2008). Akibatnya semakin tinggi prosentase dari hutang maka akan meningkatkan pula dampak dari risiko keuangannya. Carslaw dan Kaplan (1991) menyatakan bahwa solvabilitas berpengaruh di tahun 1988, namun tidak berpengaruh tahun 1987 pada sampel perusahaannya.

Dalam penelitian Wirakusuma (2004) menyatakan bahwa adanya pengaruh rasio solvabilitas terhadap audit report lag. Semakin besar rasio hutang/kewajiban terhadap total asset maka akan semakin lama rentang waktu audit report lag. Sedangkan menurut Fadoli (2014) menyatakan juga bahwa tingkat solvabilitas berpengaruh positif terhadap audit report lag.

\section{Ukuran Perusahaan}

Ukuran dalam sebuah perusahaan merupakan sketsa besar kecilnya perusahaan yang ditentukan dari ukuran nominal seperti jumlah kekayaan dan total penjualan perusahaan dalam satu periode akuntansi (Rahayu 2011). Mengukur sebuah perusahaan dapat dilihat dari total asset yang dimiliki oleh perusahaan. Hubungan antara ukuran perusahaan dengan audit report lag merupakan ukuran dari sebuah perusahaan besar yang akan menyelesaikan proses auditnya lebih cepat dibandingkan perusahaan yang levelnya kecil atau menengah. Adapun beberapa faktor yang mempengaruhi seperti manajemen perusahaan yang berskala besar cenderung memberikan insentif untuk mengurangi dampak audit report lag karena biasanya perusahaan tersebut dipantau oleh investor, pengawas permodalan, dan pemerintah. Menurut Hanifah (2001), Lianto dan Kusuma (2010) menyatakan bahwa ukuran perusahaan berpengaruh positif terhadap audit report lag sedangkan Petronila (2007) menyatakan bahwa ukuran perusahaan berpengaruh negatif terhadap audit report lag. Sedangkan menurut Parwati dan Suhardjo (2009), Tiono dan Jogi (2012) menyatakan bahwa ukuran perusahaan itu tidak berpengaruh terhadap audit report lag.

\section{Kerangka Konseptual}

Model penelitian yang digunakan dalam penelitian ini :

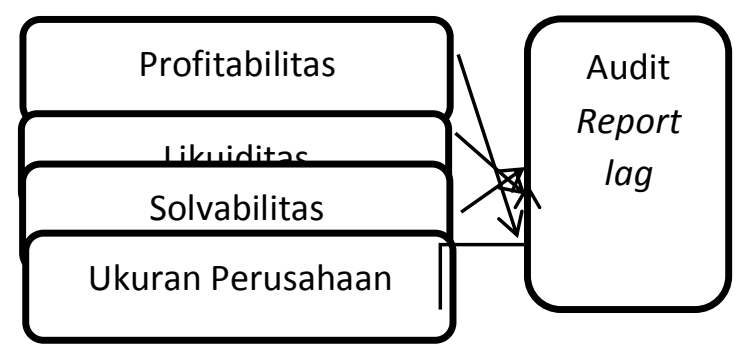

$$
\begin{aligned}
& \text { Hipotesis : } \\
& \text { H1 : Pengaruh profitabilitas terhadap }
\end{aligned}
$$

\section{METODOLOGI PENELITIAN}

Dalam penelitian ini menggunakan pendekatan berbentuk kausal yang bertujuan untuk mengetahui bagaimana pengaruh variabel independen terhadap variabel dependen. Penelitian ini dilakukan pada perusahaan manufaktur yang terdaftar dalam Bursa Efek Indonesia (BEI) yang menyediakan informasi laporan keuangan periode 2013-2015, yang dapat diakses melalui website www.idx.co.id. Perusahaan

manufaktur dipilih pada satu jenis perusahaan manufaktur, karena perusahaan manufaktur merupakan perusahaan yang paling banyak 
terdaftar di BEI, sehingga variasi data yang digunakan untuk sampel penelitian yang diperlukan akan semakin banyak.

Objek penelitian ini adalah perusahaan manufaktur yang terdaftar di Bursa Efek Indonesia periode 2013-2015. Variabel dependent (Y) adalah audit report lag. Audit report lag merupakan aspek penting dalam ketepatan waktu informasi yang dibutuhkan para pengguna laporan keuangan. Audit report lag melihat dari lamanya waktu dalam penyelesaian audit yang diukur dari tanggal tutup buku sampai tanggal diterbitkannya laporan keuangan perusahaan yang telah diaudit (Soetedjo, 2006).

Variabel terikat dalam penelitian ini adalah Audit Report lag yang merupakan jarak waktu tanggal berakhirnya tutup buku sampai tanggal diterbitkannya laporan keuangan. Variabel bebas dalam penelitian ini terdapat tiga variabel bebas yaitu Profitabilitas, Likuiditas, Solvabilitas, serta Ukuran Perusahaan.

Rasio profitabilitas dalam penelitian ini dengan menggunakanreturn on assets (ROA). Return On Assets (ROA) merupakan rasio yang menunjukkan hasil atas jumlah aktiva yang digunakan oleh perusahaan berdasarkan perbandingan antara laba bersih setelah pajak dengan total aktiva.

Sedangkan likuiditas menghitung dengan melihat jumlah hutang jangka pendek dengan jumlah asset. Kemudian solvabilitas yang digunakan dalam penelitian ini diukur dengan membandingkan jumlah utang jangka panjang dengan jumlah aktiva. Lalu ukuran perusahaan merupakan patokan dari besar kecilnya suatu perusahaan yang diukur dengan menggunakan jumlah aktiva (Petronila, 2007). Ukuran perusahaan dihitung nilai logaritma total aktiva perusahaan pada akhir tahun. Data kuantitatif adalah data kualitatif (Sugiyono, 2014:14). Data kuantitatif yang digunakan dalam penelitian ini berupa laporan keuangan perusahaan manufaktur terdaftar di Bursa Efek Indonesia periode 2013-2015 melihat dari profil perusahaan, struktur organisasi serta catatan atas laporan keuangan perusahaan manufaktur.

Sumber data yang digunakan dalam penelitian ini menggunakan data sekunder. yang diperoleh dari pihak lain yang sebelumnya telah dikumpulkan, diolah dan dipublikasikan, selanjutnya dilakukan proses analisis dan interpretasi sesuai dengan tujuan penelitian (Sugiyono:2014). Data sekunder yang digunakan dalam penelitian ini adalah data laporan keuangan tahunan yang diaudit melalui website www.idx.co.id. Populasi yang digunakan dalam penelitian ini adalah perusahaan manufaktur yang terdaftar di Bursa Efek Indonesia (BEI) periode 2013-2015 yang berjumlah 105 perusahaan.

Dalam penelitian ini, sampel ditentukan dengan menggunakan metode non probability sampling dengan teknik purposive sampling, yaitu metode penentuan sampel dengan pertimbangan tertentu, dimana anggota sampel akan dipilih sehingga sampel yang dibentuk dapat mewakili sifat-sifat populasi (Sugiyono,2014).

Metode analisis yang digunakan dalam penelitian ini adalah analisis regresi linier berganda. Analisis regresi linier berganda digunakan untuk menguji pengaruh antara audit report lag dengan variabel bebas (independen). Uji analisis dengan regresi linier berganda adalah mencari pengaruh profitabilitas (X1), likuiditas (X2) solvabilitas (X3), dan ukuran perusahaan (X4) terhadap audit report lag. Model regresi linier berganda yang digunakan adalah dengan menggunakan rumus (Wirawan, 2002:293) :

$\mathrm{Y}=\mathrm{a}+\beta 1 \mathrm{X} 1+\beta 2 \mathrm{X} 2+\beta 3 \mathrm{X} 3+\mathrm{e}$

......................................

Keterangan:

$\mathrm{Y}=$ Audit Report lag

$\mathrm{a}=$ Konstanta

$\beta 1-\beta 3=$ Koefisien regresi dari $X 1, X 2, X 3$ X1 = Profitabilitas

$\mathrm{X} 2$ = Solvabilitas

X3 = Ukuran Perusahaan

$\mathrm{e}=$ Error

\section{HASIL PEMBAHASAN}

Populasi yang digunakan dalam penelitian ini adalah perusahaan manufaktur yang terdaftar di Bursa Efek Indonesia (BEI) periode 2013-2015 yang berjumlah 105 perusahaan dengan data statistic deskriptif pada variable penelitian.

Tabel 1.Perusahaan Yang Menjadi Sampel

\begin{tabular}{|l|l|c|}
\hline No & \multicolumn{1}{|c|}{ Kriteria } & Jmlh \\
\hline 1 & $\begin{array}{l}\text { perusahaan manufaktur yang } \\
\text { terdaftar di BEI tahun 2013-2015 }\end{array}$ & 105 \\
\hline 2 & $\begin{array}{l}\text { Perusahaan yang tidak } \\
\text { menerbitkan laporan keuangan }\end{array}$ & $(0)$ \\
\hline 3 & $\begin{array}{l}\text { Laporan keuangan tidak berakhir } \\
31 \text { Desember dan tidak } \\
\text { dinyatakan dalam rupiah }\end{array}$ & $(12)$ \\
\hline 4 & Perusahaan yang melaporkan rugi & $(29)$ \\
\hline Jumlah Sample & $\mathbf{6 4}$ \\
\hline
\end{tabular}

Dalam Uji Normalitas dikatakan berdistribusi normal apabila tingkat signifikansinya 
menunjukkan nilai yang lebih besar dari 0,05 . Hasil uji normalitas dapat dilihat pada Tabel 2.

Tabel 2.Hasil Uji Normalitas

\begin{tabular}{|ll|r|}
\hline & \multicolumn{1}{|c|}{$\begin{array}{c}\text { Unstandar- } \\
\text { dized } \\
\text { Residual }\end{array}$} \\
\hline $\mathrm{N}$ & 64 \\
Normal & Mean &, 0000000 \\
Parameters ${ }^{\mathrm{a}, \mathrm{b}}$ & Std. Deviation & 11,06638419 \\
Most Extreme & Absolute &, 211 \\
Differences & Positive & Negative \\
Kolmogorov-Smirnov Z &,- 211 \\
Asymp. Sig. (2-tailed) & 1,054 \\
\hline
\end{tabular}

a. Test distribution is Normal.

b. Calculated from data.

Berdasarkan pengujian pada Tabel 2, diperoleh sig (2-tailed) sebesar 0,217 lebih besar dari 0,05 . Hal ini menunjukkan bahwa dari hasil tersebut telah berdistribusi normal. Untuk menguji ada tidaknya multikolinearitas dapat digunakan nilai tolerance atau VIF (variance inflation factor). Hasil dari uji multikoliniaritas dapat dilihat pada Tabel 3.

Tabel 3. Hasil Uji Multikoliniaritas

\begin{tabular}{|l|r|r|r|r|}
\hline \multirow{2}{*}{ Model } & \multicolumn{2}{|c|}{$\begin{array}{c}\text { Unstandardized } \\
\text { Coefficients }\end{array}$} & \multicolumn{2}{|c|}{$\begin{array}{c}\text { Collinearity } \\
\text { Statistics }\end{array}$} \\
\cline { 2 - 6 } & \multicolumn{1}{|c|}{ B } & $\begin{array}{c}\text { Std. } \\
\text { Error }\end{array}$ & Tolerance & VIF \\
\hline 1 (Cons & 84,189 & 12,622 & & \\
& & & & \\
tant) & $-17,230$ & 6,759 &, 993 & 1,007 \\
X1 &,- 428 & 5,161 &, 963 & 1,039 \\
X3 & $-21,300$ & 7,377 &, 978 & 1,023 \\
X4 &,- 183 & 1,187 &, 973 & 1,028 \\
\hline
\end{tabular}

a. Dependent Variable: $Y$

Berdasarkan hasil dari Tabel 3 terlihat bahwa semua variabel independen mempunyai nilai tolerance di atas 0,9 dan nilai VIF dibawah 10. Hal tersebut menunjukkan bahwa tidak terjadi multikoliniaritas.

Suatu data dikatakan tidak mengandung heteroskedastisitas apabila signifikansinya di atas 0,05 . Hasil uji diperoleh tidak ada variabel bebas yang berpengaruh signifikan. Hasil uji heteroskedastisitas dapat dilihat pada Tabel 4.

Tabel 4. Hasil Uji Heteroskedastisitas

\begin{tabular}{|ll|r|r|}
\hline Model & \multicolumn{2}{|c|}{ t } & Sig. \\
\hline $\begin{array}{l}\text { (Consta } \\
\text { nt) }\end{array}$ & 6,670 &, 000 \\
\hline
\end{tabular}

\begin{tabular}{r|r|r|}
$\mathrm{X} 1$ & $-2,549$ &, 019 \\
$\mathrm{X} 2$ &,- 083 &, 935 \\
$\mathrm{X} 3$ & $-2,888$ &, 009 \\
$\mathrm{X} 4$ &,- 154 &, 879 \\
\hline
\end{tabular}

a. Dependent Variable: Y

Berdasarkan dari hasil Tabel 4 dapat dilihat bahwa nilai signifikansi dari masing-masing variabel bebas memiliki nilai $>0,05$, sehingga dapat disimpulkan bahwa model regresi ini bebas dari gejala heteroskedastisitas.

Untuk mengetahui ada tidaknya autokorelasi, maka digunakan metode Durbin Watson. Jika nilai Dw Test sudah ada maka nilai tersebut dibandingkan dengan nilai tabel menggunakan tingkat keyakinan sebesar 95\%.

Tabel 5.

Hasil Uji Autokorelasi

\begin{tabular}{|l|r|r|r|c|}
\hline Model & $\mathrm{R}$ & $\begin{array}{c}\mathrm{R} \\
\text { Square }\end{array}$ & $\begin{array}{c}\text { Adjusted } \\
\mathrm{R} \\
\text { Square }\end{array}$ & $\begin{array}{c}\text { Durbi } \\
\mathrm{n}- \\
\text { Wats } \\
\text { on }\end{array}$ \\
\hline 1 &, $657^{\mathrm{a}}$ &, 432 &, 318 & 1,809 \\
\hline
\end{tabular}

a. Predictors: (Constant), X4, X1, X3, X2

b. Dependent Variable: Y

Berdasarkan hasil dari Tabel 5 diperoleh bahwa nilai Durbin-Watson adalah 1,809 dengan taraf signifikansi $5 \%$, untuk $\mathrm{N}=64$, jumlah variabel bebas sebanyak 4 dan sig $=0,05$ diperoleh nilai DU sebesar 1,7303 dan DL sebesar 1,4659. Oleh karena nilai dw berada pada $\mathrm{du}<\mathrm{dw}<4$-du atau $1,7303<1,809<$ 2,2697 berarti tidak terdapat autokorelasi sehingga model ini layak digunakan untuk analisis selanjutnya.

Selain itu diketahui nilai koefisien korelasi (R) sebesar 0,657 mempunyai arti bahwa tidak adanya korelasi positif atau negatif antara variabel independen dengan variabel dependen. Nilai R2 adalah 0,432 ini berarti varian dari variabel bebas yang terdiri dari profitabilitas, solvabilitas dan ukuran perusahaan mampu memperjelas variabel terikat yaitu audit report lag.

Besarnya nilai Adjusted $\mathrm{R}^{2}$ sebesar 0,318 atau 31,8 persen berarti variabilitas variabel dependen audit report lag dapat dijelaskan oleh variabilitas variabel independen yaitu profitabilitas, likuiditas, solvabilitas dan ukuran perusahaan sebesar 31,8 persen, sedangkan sisanya sebesar 68,2 persen dijelaskan oleh sebab-sebab lain diluar model regresi. 
Penyelesaian analisis regresi linier berganda ini disajikan dalam Tabel 6 berikut ini:

Tabel 6. Hasil Analisis Regresi Linier Berganda

\begin{tabular}{|ll|r|r|r|r}
\hline \multirow{2}{*}{ Model } & \multicolumn{2}{|c|}{$\begin{array}{c}\text { Unstandardized } \\
\text { Coefficients }\end{array}$} & \multicolumn{2}{c}{$\begin{array}{c}\text { Collinearity } \\
\text { Statistics }\end{array}$} \\
\cline { 2 - 6 } & \multicolumn{1}{|c|}{ B } & Std. Error & Tolerance & VI \\
\hline 1 (Cons & 84,189 & 12,622 & & \\
& & & & \\
tant) & & &, 993 & 1,0 \\
X1 & $-17,230$ & 6,759 &, 963 & 1,0 \\
X3 &,- 428 & 5,161 &, 978 & 1,0 \\
& $-21,300$ & 7,377 &, 973 & 1,0 \\
X4 &,- 183 & 1,187 &, 93 \\
a. Dependent Variable: Y
\end{tabular}

Audit Report lag $=84,189-17,230$ X1 - 0,428 $\mathrm{X} 2-21,300 \mathrm{X} 3-0,183 \mathrm{X} 4+\mathrm{e}$

Nilai konstanta sebesar 84,189. Ini menunjukkan bahwa jika nilai variabel bebas yaitu profitabilitas, likuiditas, solvabilitas dan ukuran perusahaan sama dengan nol, maka tingkat audit report lag adalah sebesar 84,189 hari. Koefisien regresi profitabilitas (X1) sebesar -17,230. Ini menunjukkan bahwa jika variabel independen lainnya dianggap konstan, maka kenaikan 1 persen profitabilitas akan mengakibatkan penurunan audit report lag sebesar 17,230 persen.

Koefisien regresi likuiditas (X2) sebesar -0,428. Ini menunjukkan bahwa jika variabel independen lainnya dianggap konstan, maka kenaikan 1 persen profitabilitas akan mengakibatkan penurunan audit report lag sebesar 0,428 persen.

Koefisien regresi solvabilitas (X3) sebesar 21,300. Ini menunjukkan bahwa jika variabel independen lainnya dianggap konstan, maka kenaikan 1 persen solvabilitas akan mengakibatkan kenaikan audit report lag sebesar 21,300 persen.

Koefisien regresi ukuran perusahaan (X4) sebesar -0,183. Ini menunjukkan bahwa jika variabel independen lainnya dianggap konstan, maka kenaikan Rp 1 rupiah ukuran perusahaan akan mengakibatkan penurunan audit report lag sebesar Rp 0,183 rupiah.

Tabel 7.

Hasil Uji t

\begin{tabular}{|c|c|c|c|}
\hline \multirow[t]{2}{*}{ Model } & \multicolumn{2}{|c|}{ Unstandardized Coefficients } & \multirow[b]{2}{*}{ Sig. } \\
\hline & B & Std. Error & \\
\hline $1 \begin{array}{l}\text { (Cons } \\
\text { tant) }\end{array}$ & 84,189 & 12,622 &, 000 \\
\hline $\mathrm{X} 1$ & $-17,230$ & 6,759 & 019 \\
\hline $\mathrm{X} 2$ &,- 428 & 5,161 & ,935 \\
\hline X3 & $-21,300$ & 7,377 & 009 \\
\hline
\end{tabular}

\begin{tabular}{l|ll|l|l|}
\hline X4 &,- 183 & 1,187 &, 879 \\
\hline
\end{tabular}

a. Dependent Variable: $Y$

Berdasarkan hasil uji t yang disajikan pada Tabel 7 bahwa nilai $\beta$ dengan signifikansi uji t menunjukkan angka lebih kecil dari taraf nyata dalam penelitian ini yaitu 0,05 . Hal ini menunjukkan variabel profitabilitas, likuiditas, solvabilitas, dan ukuran perusahaan berpengaruh terhadap audit report lag. Dengan demikian hipotesis $\mathrm{H} 1, \mathrm{H} 2, \mathrm{H} 3$, dan $\mathrm{H} 4$ diterima.

\section{SIMPULAN DAN SARAN}

Berdasarkan hasil penelitian maka dapat disimpulkan bahwa profitabilitas berpengaruh terhadap audit report lag mengindikasikan bahwa perusahaan yang mendapatkan profit yang besar cenderung melakukan proses audit lebih singkat dibanding perusahaan yang mengalami profit yang kecil, likuiditas berpengaruh terhadap audit report lag, solvabilitas berpengaruh terhadap audit report lag mengindikasikan bahwa tingginya jumlah hutang yang dimiliki perusahaan akan menyebabkan proses audit yang relatif lebih panjang, dan ukuran perusahaan berpengaruh terhadap audit report lag yang mengindikasikan bahwa besar atau kecilnya jumlah aset yang dimiliki oleh perusahaan mempunyai mempengaruhi panjang atau pendeknya proses penyusunan laporan keuangan pada perusahaan tersebut

Dengan itu peneliti mengajukan beberapa saran, yaitu mengingat pada penelitian ini diperoleh nilai koefisien determinasi (adjusted R Square) yang rendah maka peneliti menyarankan untuk menambahkan variabel-variabel bebas lain yang secara teori dapat mempengaruhi audit report lag. Penelitian ini memberikan saran agar menambah variable lain yang mempengaruhi audit report lag, serta tahun periode pengambilan sample, dan sebaiknya menambah beberapa sector dari perusahaan manufaktur yang terdaftar di Bursa Efek Indonesia.

\section{DAFTAR PUSTAKA}

1. Amin Widjaja Tunggal, 1995, Dasar-Dasar Analisis Laporan Keuangan, Cetakan Pertama, Jakarta : PT. Rineka Cipta.

2. Ang, Robert, 1997, Buku Pintar Pasar Modal Indonesia, Jakarta: Media Staff Indonesia. 
3. Bambang Riyanto, 1995, Dasar-dasar pembelanjaan perusahaan, Edisi keempat. Yogyakarta, Yayasan Penerbit Gajah Mada.

4. Chistiawan, Yulius Jogi dan Christian Noverta Togasima, 2014, Analisis FaktorFaktor Yang Mempengaruhi Audit Report lag Pada Perusahaan Yang Terdaftar Di Bursa Efek Indonesia Pada Tahun 2012, Akuntansi Bisnis Universitas Kristen Petra.

5. Eldon S. Hendriksen, Michael F Van Breda. 2000, Teori Akunting, Jilid Dua, Batam : interaksara.

6. Fadoli, Imam, 2014, Pengaruh Faktor Internal Dan Eksternal Terhadap Audit Report lag, Fakultas Ekonomi Universitas Pandanaran.

7. Hilmi, Utari. Dan Ali, Syaiful, 2008, Analisis Faktor-Faktor yang Mempengaruhi Ketepatan Waktu Penyampaian Laporan Keuangan, Simposium Nasional Akuntansi XI Ikatan Akuntan Indonesia. H.1-22.

8. Munawir, 2001, Akuntansi Keuangan dan Manajmen, Edisi Pertama, BPFE, Yogyakarta.

9. Lianto, Novice dan Budi Hartono Kusuma, 2010, Faktor - Faktor Yang Berpengaruh Terhadap Audit Report lag, Jurnal Bisnis Dan Akuntansi, Fakultas Ekonomi Universitas Tarumanegara, Vol.12, No. 2, hal. 97-106.

10. Listiana, Lisa dan Tri Pujadi Susilo, 2010, Faktor - Faktor Yang Mempengaruhi Reporting Lag Perusahaan, Fakultas Ekonomi dan Ilmu Sosial Universitas Bakrie, ISNN 2088-2106.

11. Petronila, Thio Anastasia, 2007, Analisis Skala Perusahaan, Opini Audit dan Umur Perusahan atas Audit Report lag, Akuntabilitas, Maret 2007, hal. 129-141.

12. Rachmawati, Sistya, 2008, Pengaruh Faktor Internal dan Eksternal Perusahaan terhadap Audit Report lag dan Timeliness, Jurnal Akuntansi dan Keuangan, Vol. 10, No. 1, hal. 1-10.
13. Sekaran,Uma, 2003, Research Methods for Business : A Skill Building Approach $2^{\text {nd }}$ Edition, John Wiley and Son, New York.

14. Soetedjo, Soegeng, 2006, Faktor - Faktor Yang Mempengaruhi Audit Delay Log (ARL), Vol. 9, No. 2 Agustus, pp: 77 - 92.

15. Subekti, Imam dan Novi Wulandari W, 2004, Faktor - Faktor Yang Mempengaruhi Audit Report lag di Indonesia, Simposium Nasional Akuntansi VII Denpasar - Bali, 23 Desember, hal. $991-1001$.

16. Sugiyono. 2014, Metode Penelitian Kuantitatif, Kualitatif, dan Kombinasi (Mixed Methods), Bandung : Alfabeta

17. Sumartini, Ni Komang Ari, Ni Luh Sari Widhiyani, 2014, Pengaruh Opini Audit, Solvabilitas, Ukuran KAP dan Laba Rugi Pada Audit Report lag, Fakultas Ekonomi dan Bisnis Universitas Udayana.

18. Swami, Dewiyani dan Yeni Latrini, 2013, Pengaruh Karakteristik Corporate Governance Terhadap Audit Report lag, EJournal Ekonomi Universitas Udayana, Fakultas Ekonomi Universitas Udayana.

19. Tiono, Ivena Dan Yulius Jogi C, 2013, Faktor-Faktor Yang Mempengaruhi Audit Report lag Di Bursa Efek Indonesia, Akuntansi Bisnis Universitas Kristen Petra .

20. Wirakusuma, Made Gede, 2004, Faktor Faktor Yang Mempengaruhi Rentang Waktu Penyajian Laporan Keuangan Ke Publik: Studi Empiris Mengenai Keberadaan Divisi Internal Audit pada Perusahaan Perusahaan yang Terdaftar di Bursa Efek Jakarta, Simposium Nasional Akuntansi VII Denpasar - Bali, 2-3 Desember, hal. 1202 1223.

21. Yetawati, Made, 2013, Analisis Faktor Faktor yang Berpengaruh Terhadap Audit Delay Pada Perusahaan Manufaktur Di Bursa Efek Indonesia, Skripsi, Universitas Warmadewa-Bali. 